\title{
UNIVERSITYOF
}

FORWARD

THINKING

WESTMINSTER ${ }^{\text {用 }}$

WestminsterResearch

http://www.westminster.ac.uk/westminsterresearch

Coordinating internal immigration control in the UK

Sitkin, L.

This is an author's accepted manuscript of an article published in the International Journal of Migration and Border Studies, 1 (1), pp. 39-56, 2014.

The final definitive version is available online at:

https://dx.doi.org/10.1504/IJMBS.2014.065068

(C) 2014 Inderscience Enterprises Ltd.

The WestminsterResearch online digital archive at the University of Westminster aims to make the research output of the University available to a wider audience. Copyright and Moral Rights remain with the authors and/or copyright owners.

Whilst further distribution of specific materials from within this archive is forbidden, you may freely distribute the URL of WestminsterResearch: ((http://westminsterresearch.wmin.ac.uk/).

In case of abuse or copyright appearing without permission e-mail repository@westminster.ac.uk 


\section{Coordinating internal immigration control in the UK}

\section{$\underline{\text { International journal of migration and border studies }}$}

Keywords: immigration enforcement; internal migration control; border control; deputisation; pluralisation; irregular immigrant's access to social services; control of illegal foreign employment.

\section{Lea Sitkin}

\section{Lea.sitkin@gtc.ox.ac.uk}

DPhil candidate, Centre for Criminology, University of Oxford, Manor Rd. Building, Manor Rd., Oxford, OX1 3UQ, UK

Biographical notes: Lea Sitkin's academic research focuses on the organisation and effects of immigration controls, the relationship between neoliberalism, welfare and punishment and the development of precarious labour markets across Europe and the USA. Her doctoral research uses a comparative case study (UK and Germany) to interrogate materialist explanations for punitive transformations in immigration control in Europe. The thesis offers a historical analysis for why immigrant communities are policed differently in the two contexts. It also explores the role of underlying labour market variation (as described in the Varieties of Capitalism literature) on the construction of immigrants as vulnerable workers in the UK and Germany. Previous research has focused on the generalizability of Wacquant's Punishing the Poor (2009) to the European context. 


\begin{abstract}
$\underline{\text { Abstract }}$
The UK government has recently introduced measures to intensify the internal migration control regime by improving coordination between immigration authorities and third-party enforcement agents. The following paper describes the internal migration control regime in the UK, focusing on measures developed to impede irregular migrants' access to work, justice, healthcare, education and housing. It also explores the ways in which coordination between actors comprising the "immigration policing family" is hampered by administrative difficulties and, more fundamentally, by a lack of common goals. In response to these issues, successive UK governments have introduced sanctions for non-compliant enforcement agents, which are often discursively linked by immigration authorities to the notion of preventing third parties' exploitation of irregular migrants. However, ultimately it is the developing internal control regime which threatens irregular migrants' survival.
\end{abstract}


1. Introduction: Internal immigration control and the development of the "immigration policing $\underline{\text { family" }}$

"Besides the Home Office, other bodies in the public and private sectors have a role to play in making it difficult for illegal migrants to remain in the country"1

"Frankly, it is too easy to be an illegal immigrant in Britain today"”

While the word "border" brings to mind the physical boundaries encompassing the nationstate, there are points of control and surveillance at several points on the migratory journey (Guiraudon and Joppke, 2001; Broeders and Engbersen, 2007). Migration control in the UK has, for instance, been pushed "outwards" to foreign consulates issuing visas in Mumbai, Cape Town and Pattaya; pre-boarding checks at international airports; and to interdiction efforts in EU boundary countries such as Soviet Republics and Turkey (Lahav, 1998). At the same time, controls have increasingly been shifted "inwards", targeting foreigners who have already entered the national space. These internal controls work in two ways: first, by preventing migrants from gaining access to a job, service or home to which they are not entitled; second, by ensuring that irregular migrants (or those who are facilitating their stay) come to the attention of the authorities (Vogel, 2000).

Internal immigration controls require enforcement by a diffuse and pluralised network of actors. On the one hand, there is the network of state organisations for whom immigration enforcement is a central or defining part of their purpose. In the UK, the UK Border Agency's enforcement duties have recently been siphoned into the "Immigration Law Enforcement" unit within the Home Office. On the other hand, successive UK governments have "deputised"3 third parties for immigration enforcement, such as trade unions, employers, landlords, school teachers, doctors, labour inspectors, police officers, universities and welfare services. These actors do not have immigration control as defining purpose, but have increasingly been brought into the control matrix.

Over the past twenty years, the UK government has increasingly shifted its focus from external to internal controls. More recently, the Immigration Act 2014 promises to intensify the internal 
immigration control regime by fostering stronger coordination between the different actors charged with immigration enforcement tasks. However, coordination of what might be called the "immigration policing family"4 is often undermined by competition, conflict and a lack of common goals. Third parties may resist the task of immigration enforcement for ideological reasons. For instance, doctors' duty of patient care may prevent them from alerting the immigration authorities where irregular immigration is suspected. Third parties to whom immigration control tasks have been delegated might also find a commercial advantage in not complying with enforcement requirements. One example would be the benefits that some employers derive from illegal foreign employment, such as paying lower wages (Karlson and Katz, 2003; Jones, Ram et al., 2006).

As a result, the intensification of internal immigration control is politically controversial. Given the fact that allegiance of third parties to immigration enforcement cannot be assumed, coordination between the different parties responsible for immigration control can often only be achieved through punitive measures. Although the general principle is for migration control to target irregular migrants themselves, at times is it the non-compliant third parties who become the objects of punishment (Broeders, 2009). As the following article explores, the introduction of third-party sanctions is often discussed by the government in terms of the desire to protect irregular immigrants from exploitation by "rogue landlords" or "exploitative employers", as well as to safeguard the sanctity of the immigration admissions regime. On the other side, reluctant third parties also pay homage to immigrants' welfare, as well as "British values", such as freedom, privacy, compassion or fairness when they are attempting to resist the imposition of immigration duties. Thus, the battles of internal immigration control offer an interesting site for exploring the construction of British value systems, as well as the way in which representations of immigrants' welfare are manipulated in political debate.

The current contribution is structured in such a way as to highlight the key nodes where current internal immigration control plays out: access to work; access to justice; access to healthcare; access to education; and access to housing. While the following sections focus primarily on the complexity of coordinating different enforcement agents - and the politics around the imposition of internal control duties- the issue of control measures' impacts on irregular migrants is discussed at the end of the article. 


\section{Nodes of control}

\section{a. Access to work}

Enforcement against unauthorised foreign employment ${ }^{5}$ requires a system of control that permeates the national labour market. As such, the UK has controls when the job applicant approaches the employer, as well as workplace inspections. Immigration checks during the application stage are primarily carried out by employers - perhaps the most obvious group within the "immigration policing family" for whom non-compliance reaps financial rewards. Cooperation is "encouraged" through sanctions where employers do not carry out appropriate documentary checks on the right to work. At the time of introduction in 1996, sanctions were strongly resisted by employers' associations, who resented the additional burden controls implied. They also argued that many employers would respond to the risk of prosecution by refusing to employ ethnic minorities. ${ }^{6}$ The result of political dissent was a system which was weak in several respects, and which was the subject of significant reform attempts (Ryan, 2007).

Since the Immigration, Asylum and Nationality Act 2006, a dual system of sanctions has been in place in the UK, with "on the spot" civil penalties of up to $£ 10,000$ per worker intended for the vast majority of employers, who hire unauthorised immigrants "careless[ly]"7 and criminal sanctions reserved for employers who "knowingly" employ undocumented migrants. A statutory defence exists as long as employers have checked certain documents. The draft Immigration (Employment of Adults Subject to Immigration Control) (Maximum Penalty) (Amendment) Order 2014 contains provisions to increase the total penalty per worker to $£ 20,000$.

The introduction of civil sanctions has facilitated the punishment of employers for the unauthorised employment of foreign nationals. However, a key issue with the current system is that it places verification of a potential employees' right to work in the hands of non-experts: employers. Previously, employers had very little access to information that could help them make a decision as to the validity of the documents given to them by their employee. However, "biometric residence 
permits" (BRPs) introduced in 2008 for foreign nationals can be checked against a nationwide database through an online checking service (Warren and Mavroudi, 2011). This new system represents a significant tightening of the enforcement regime, although it still depends upon employers' cooperation and judgement and will not prevent foreign workers from presenting forged EU identity documents.

The other check at the application stage concerns the allocation of National Insurance numbers, which is an "administrative indicator used by the Department of Work and Pensions and [Her Majesty's Revenue and Customs] to record Tax and National Insurance contributions and payments of benefits." ${ }^{8}$ All job applicants must present their National Insurance numbers to their employers during the application stage. Notably, until 2005, the issuing body - the Department of Work and Pensions (DWP) - instructed Jobcentre staff to issue National Insurance numbers even when there was evidence that immigration status had been falsified. This was because "any prosecution action in respect of the falsified immigration documentation would be the responsibility of [the immigration and nationality directorate] ${ }^{9}-$ NOT THE [DEPARTMENT OF WORK AND PENSIONS]." 10

This remarkable instruction is an indication of the particular coordination problems that the UK "immigration policing family" faces. Following media outcry, the enforcement regime has tightened considerably. Today, "all cases are checked for the right to work"11 before a National Insurance number is allocated. In addition, the Department of Work and Pensions are permitted ${ }^{12}$ to share information on illegal immigration with the UKBA, although they do not record how often this occurs and what particular information they have forwarded. It is therefore uncertain the extent to which discovery of irregular status by the DWP implies notification of the immigration authorities.

Nonetheless, it has clearly become much harder for irregular migrants to gain access to National Insurance numbers in recent years. However, it is worth noting that National Insurance numbers are readily available on the black market - partially because they do not expire when right to leave or work runs out - and can be easily used by imposters, in part because they contain no biometric data (Düvell, 2008: 198). Thus, the control regime is not airtight. 
In terms of the inspection regime, the Civil Penalty Compliance team - formerly part of the UK Border Agency - is responsible for checking that employers are fulfilling their duties at the gate of employment. The unit is not large - in 2011, only 41 members of staff worked on the Civil Penalty Compliance Team. ${ }^{13}$ Before conducting an inspection, inspectors are required to have a "reasonable suspicion" based on facts, information and/or intelligence - relevant to a specific workplace or to individual workers - that immigration laws have been or are being breached (Trade Union Congress, 2010). Thus, the vast majority of workplace raids carried out by the team are in response to denunciations. Finally, the Civil Penalty Compliance team carried out 5,083 illegal working enforcement visits in $2011^{14}$ - a decline from the 7,178 workplace visits conducted between April 2007 and March 2008. ${ }^{15}$ Falling inspection figures indicate the team's shrinking resources, which can be seen in the context of the current Conservative-Liberal government's attempt to reduce the national budget through cutting public services. ${ }^{16}$ It is unclear what the impact of organisation restructuring (the abolishment of the UKBA after being designated "unfit for purpose" and the establishment of a new Immigration Law Enforcement division) will be on the UK's workplace inspection regime.

The Civil Penalty Compliance team is also assisted in its work by other departments involved in the control of illegal work. Importantly, the UK has no general system of labour inspection. Instead, there are many different agencies concerned with different aspects of the shadow economy, including: the Department for Work and Pensions, which is primarily concerned with benefit fraud; the Gangmasters' Licensing Authority, which concentrates on the supply of labour in agriculture, horticulture and the shellfish industry; the Health and Safety Inspectorate, which focuses on health and safety standards in the workplace, and so forth. The end result of this fragmented institutional environment is that informal employment means different things to different departments and labour inspectors do not have the same priorities as one another.

Joint working is rare because of "the different priorities and objectives" of the agencies. ${ }^{17}$ For instance, according to Health and Safety Executive (HSE) guidance on joint working with the former UK Border Agency, "officers should not be distracted from their primary statutory function," 18 which is to enforce health and safety standards. Visiting HSE inspectors were warned that passing information to the UKBA could result in the rapid deportation of potential witnesses, turning on some 
occasions into "life or death" situations. ${ }^{19}$ Here, the contradictions of simultaneously enforcing immigration law and labour standards are considered in an explicit fashion.

A notable feature of the UK control regime is that cooperation with the immigration authorities varies from department to department. For instance, in the past 3 years, the Gangmasters' Licensing Authority passed on information to the UKBA 285 times $^{20}$ while the Health and Safety Executive only did so once. ${ }^{21}$ The difference between the two agencies can be explained by the fact that the Gangmasters' Licensing Authority was founded in response to the deaths of a group of illegally resident Chinese cockle-pickers at Morecombe Bay. From the start, the task of immigration enforcement was a given part of the Authority's remit.

In recent years - and particularly since the damning judgments contained in the Treasury's "Grabiner report" on Illegal working (2000)22 - there have been some efforts to improve interdepartmental coordination. ${ }^{23}$ For instance, until 2012, Her Majesty's Revenue and Customs (HMRC), which holds data on employment and tax contributions, explicitly rejected "bulk data matching" with the records collected by the UKBA, for fear of repercussions under the Data Protection Act (1998). ${ }^{24}$ Fear of criminal prosecution for the wrongful disclosure of HMRC information (section 42 of the 2007 Act) means that information sharing only occurred in the UK on a case-by-case basis. However, in the past year, the guidance has changed so that bulk data matching does occur, although records are not kept of its use. The legality of such measures regarding data protection issues has not been investigated.

\section{b. Access to justice}

The role of the police immigration enforcement has changed dramatically over the years. In the 1970s, the police were primarily responsible for what little internal immigration enforcement took place during this period. ${ }^{25}$ Today, the police take a "key" if secondary role in immigration enforcement. Statistics are patchy, but it appears most police action on immigration is concentrated in London: in 2011-2012 the London Metropolitan police conducted 5,152 arrests for immigration, compared to 348 in Devon and 97 in Suffolk in $2011 .{ }^{26}$ A Home Office report on policing found a 
regular flow of arrestees picked up "purely on the basis of their immigration status", as a result of either "lorry-stop drop-off" operations or joint immigration/police actions (Hamilton-Smith and Patel, 2006).

The former UK Border Agency and police occasionally worked together in "Crime Reduction Operations" ("CrOps") where there was suspicion that immigration crime would be uncovered alongside other crimes. Nonetheless, the relationship between the police and the UKBA was relatively complicated. The first issue was competing objectives. The police resented the use of their resources - particularly, holding cells - for capturing illegal immigrants, as opposed to other, more prioritised crime control activities (Jordan, 2002). Secondly, the desire to maintain good community relations inhibited police cooperation with immigration authorities. In particular, the suffocation of Jamaican woman named Joy Gardner in the course of her arrest by immigration and police officers in 1993 was a central cause in the police's reappraisal of its role in immigration enforcement (Gibney, 2008). The need for greater sensitivity around issues of nationality was magnified by the designation of the police as "institutionally racist" in their response to Stephen Lawrence's racially motivated murder (Macpherson, 1999). More recently, joint UKBA-police force identity checks in London underground stations have invoked widespread public condemnation on the basis that they are discriminatory and contravene fundamental freedoms in Britain. ${ }^{27}$

Thirdly, the two agencies have confronted serious information sharing issues. Despite technological advances, ${ }^{28}$ police are generally unschooled in the mechanisms of identifying irregular immigrants among the general arrest population. Furthermore, the police have expressed concern that information they do pass on does not get used, as epitomised in the discovery that the UKBA failed to use data collected on the Police National Computer for tracing failed asylum seekers, claiming it was "unreliable". ${ }^{29}$ Keith Vaz MP, Chairman of the Home Affairs Select Committee, dismissed these allegations as "evidence of the UKBA's incompetence". In general, differences in data collection methods have hindered effective collaboration between the two agencies.

Finally, the police are particularly loathe to denounce migrants who are victims of crime to the immigration authorities. Arguably, the legal vulnerability of irregular immigrants renders them disproportionately vulnerable to criminal victimisation. UK police generally do not ask the 
immigration status of a victim reporting a crime, as the duty to protect a victim - and more generally, the desire not to dis-incentivise victims from reporting crime - is considered to supercede the task of immigration enforcement. However, irregular migration status can become apparent if the case goes to court. In the UK, there is no explicit prohibition against judges making a referral to the immigration authorities, although this is no duty to do so.

Whether judges find out about illegal status is another matter entirely. A key factor to consider on this level is who might be penalised by the revelation of irregular status in the courtroom. For example, in the case of claims of irregular immigrants' workplace exploitation, the prevailing doctrine of illegality states that where an employment contract is not legal, the rights that it contains are not enforceable. The implication is severe for irregular migrants, who are prevented by this measure from seeking redress in courts. However, given the severe repercussion for employers if it is found that they are knowingly hiring illegal migrants, sometimes a "cat and mouse" agreement exists between an employer and an irregular migrant that the latter's status will not be revealed..$^{30}$ This is one of the rare occasions where third party sanctions have an unwittingly positive effect on irregular migrants.

\section{c. Access to healthcare}

The right to health for undocumented migrants is outlined in various international and legally binding covenants to which the UK is a signatory. ${ }^{31}$ However, the meaning and scope of the right to health lacks clear definition (Hendriks and Toebes, 1998; Toebes, 1999; Pollard and Savulescu, 2004). The lack of conceptual clarity plays itself out in the variegated access of irregular immigrants to healthcare in the UK. In particular, both eligibility for free healthcare and third party reporting requirements in the UK depend upon whether the service is included as primary healthcare (GPs, community services) or secondary healthcare (hospitals, trusts).

Relatively strict rules are in place for secondary health care. The criterion for eligibility is "ordinary residence", which has been defined in case law 32 as both "lawful" and "settled" residence. As such, illegally resident persons are not eligible for free secondary healthcare, although patients 
requiring immediately necessary and urgent must be treated irrespective of their ability to pay. ${ }^{33}$ Anytime someone registers for secondary health care, they are meant to provide evidence that they have lived legally in the UK for a certain length of time. However, a recent consultation paper produced by the Home Office suggested that these checks were applied inconsistently across the NHS. ${ }^{34}$ Under the Immigration Act 2014, the NHS will have new responsibilities to ensure that they are properly charging where appropriate, although the details of this have yet to be worked out. There is no, as yet, any suggestion to implement sanctions for doctors or NHS staff who do not abide by immigration regulations.

The rules for primary healthcare are far more flexible. Illegal residents are eligible for free primary healthcare on the basis of their General Practitioners' approval. In turn, General Practitioners (GPs) are free to include someone into their lists, with or without documentary evidence of identity or migration status. GPs' discretion to refuse irregular immigrants is limited by the fact that any person who requires 'emergent or immediately necessary' treatment must receive that treatment free of charge for a period of up to 14 days. Furthermore, a number of practices have been threatened with legal action where they have refused to accept irregular immigrants as patients. ${ }^{35}$ Finally, if doctors choose not to provide treatment, the Primary Care Trust was until recently responsible for finding a willing GP. ${ }^{36}$ With the NHS currently going through structural flux, the future of this arrangement is unclear.

During the Immigration Bill's consultation phase, the Conservative-Liberal government outlined plans to make irregular immigrants pay for primary health care. A key argument made here was that the system "ma[de] it difficult for hospitals to administer overseas visitor treatment charges because they struggle[d] to differentiate between GP-referred patients who [we]re chargeable, and those who [we]re not." ${ }^{37}$ However, the government faced strong opposition to the introduction of eligibility requirements in primary healthcare from within the medical establishment, including the powerful British Medical Association, who "strongly oppose[d] any system where GPs were required to act as UK Border Force agents." ${ }^{38}$ The counterproductive effect of checks were also discussed by Royal College of General Practitioners chair Clare Gerada, who said immigrants with highly- 
infectious conditions could end up "wandering around for fear of being charged" or going to emergency units that were far more expensive to run than doctors' surgeries. ${ }^{39}$ Here, the argument of efficiency comes to the fore. Finally, national AIDS Trust chief executive Deborah Jack said the changes would "undermine years of work" to encourage at-risk groups to access HIV testing and treatment. $^{40}$

Notably, even at the proposal stage, there was no suggestion that GPs - or indeed, any doctor, medical or non-medical professional - would be bound to pass information to immigration authorities if they discovered illegal residence (Kmietowicz, 2004; Singer, 2004: 1904). Health professionals present themselves as strongly driven by the duty of care, which is seen as contradictory with immigration enforcement. With regard to their duty to confidentiality, regulations further stipulate that "while there is a public interest argument for reporting the patient's immigration status", the decision to report information must be weighed against "the medical needs of the patient and the wider public". ${ }^{41}$ Obligations of medical confidentiality outlined in the NHS Constitution prohibit the disclosure to third parties of patient information by the NHS and/or by other medical practitioners. Still, it is not defined whether confidentiality is limited to medical information or to any information about the patient, which could include contact details and immigration status. Furthermore, case law has established that medical confidentiality can be overridden by "public interest", albeit only under "very special circumstances". ${ }^{42}$

Still, there is some evidence of increased denunciation by the NHS to the immigration authorities. A memorandum of understanding declared that the NHS Protect - the operating name for the Counter Fraud and Security Management Service - would both "inform UKBA where any instances of suspected immigration offences [came] to light" and "respond to information requests", subject to confidentiality agreements. Since 1 Jan 2012, the NHS Protect has passed information on to the former UKBA on 82 occasions. ${ }^{43}$ A lawyer interviewed for this study also mentioned that he had represented "several cases" where NHS professionals had passed on his clients' information to the UKBA. In the end, clients became "too fearful" to proceed. ${ }^{44}$ Anecdotal evidence also suggests that the threat of denunciation is being used to deter irregular immigrant accessing healthcare. A Migrant Rights Network report presented a case study where an illegally resident pregnant woman was told 
that, "If you need treatment, you'll have to pay for it privately or go to Urgent Care Centre or A\&E, and your details will be passed to our Counter-Fraud team and the Home Office." ${ }^{45}$ As the examples here emphasise, access to secondary healthcare does carry a small degree of risk of discovery for irregularly resident migrants - a fact that may operate as a sufficient deterrent to their use of health services. Nonetheless, in a context of generally strong resistance to the mixing of clinical and immigration objectives, it would be difficult to fathom what sorts of policies would augur systematic cooperation between the two agencies. As such, it is likely that the implementation of new immigration duties for hospital staff under the Immigration Act 2014 will be problematic.

\section{d. Access to education}

Children's right to education - irrespective of their immigration status - is a principle enshrined in international law. There are approximately 120,000 school aged children in the UK who are in the country illegally (Sigona and Hughes, 2012: vii). In the UK, all Local Education Authorities (LEAs) have a duty under Section 13 of the Education Act 1996 to provide a school place for every child aged 4 through 16 residing on a temporary or permanent basis in the catchment area. Irregularly resident children are entitled to attend publicly funded schools. In order to safeguard this right, there is no obligation for a UK education authority or school to request proof of a child's immigration status or any duty of disclosure forcing schools to divulge information to the immigration authorities.

Proposals to introduce school controls and disclosure requirements were met with particularly strong opposition. In March 2013, a series of leaked emails from a government taskforce called the "Inter-ministerial group on migrants' access to benefits and public services" indicated that they were considering changing the rules around the role of schools in immigration enforcement. ${ }^{46}$ One email read: "barring children, whatever their migrant status, from compulsory education has pretty much been ruled out by ministers and at the moment is off the table... The question now is whether, if not to enforce a ban, it would nevertheless be helpful to carry out migrant status checks as part of school admissions." 47 
The teachers' unions reacted swiftly and angrily to the suggestion that controls might be introduced. Lesley Gannon, National Association of Head teachers argued that children should not be held "responsible for the actions of their parents, it's simply not fair." 48 Notably, Christine Blower of the National Union of Teachers compared the introduction of immigration enforcement in health and welfare: "We have heard politicians talk of immigrants as 'health tourists'. This is unacceptable. The Government must not create conditions that imply that the children of immigrants are 'education tourists'." 49 In both of these cases, the innocence of children is used to justify their particular exemption from immigration enforcement - a discourse which also underlies the recent ban on children in immigration removal centres (Anderson, 2012). The duty to protect the innocent clearly carried weight: while, as above, health checks have been introduced, the immigration ministry were quick to withdraw the aforementioned plans to introduce checks in schools.

Still, the fact that schools and LEAs require proof of a pupil's address is likely to pose significant difficulties to irregular migrants, who may not have such a thing as a permanent address (see section on housing) (Sigona and Hughes, 2012). Furthermore, the situation changes drastically once a child reaches the age of compulsory education at 16. In terms of further education (age 16-19), the Learner Eligibility Guidance (Young People's Learning Agency and the Skills Funding Agency 2010) states that a pupil must lawfully reside in the United Kingdom to obtain a free place. However, there is no regulation stipulating that schools must pass information pertaining to students' migration status.

Universities, by contrast, are more tightly interwoven into immigration enforcement. All prospective students from non-EU countries must have a Tier 4 student visa. ${ }^{50}$ In turn, the University must have a sponsorship license and fulfil several duties like contacting the immigration authorities when the student fails to enrol, misses ten expected contact sessions or more generally is suspected of breaking the conditions of stay. Between 2011-2012, a nation-wide campaign regarding the misuse of student visas and the proliferation of bogus colleges led to almost half of all educational institutions being struck off the approved Tier 4 sponsorship list. ${ }^{51} \mathrm{~A}$ high profile recent example was when London Metropolitan University lost its sponsorship licence for "a number of serious breaches of their 
sponsor duties." ${ }^{52}$ The decision left 2,700 non-EU overseas students in limbo, with many of them facing a choice between transferring to another university or leaving the country. ${ }^{53}$

Given the huge financial loss implied in losing sponsorship, universities are strongly compelled to abide by requirements. However, the lack of substantial public and civil backlash in these cases indicates that irregular immigrants' access to university education is conceptualised differently to pre-16 education - namely, as a luxury rather than a right. While university staff may be somewhat reluctant to be co-opted into immigration enforcement, they do not do so from the perspective of human rights, but on the basis of the extra burden it implies, as well as the lack of clarity in guidance from the former UKBA. ${ }^{54}$ More generally, the University and College Union oppose the inclusion of overseas students in the immigration cap on the basis that it damages British universities" "reputation for excellence" and "standing on the global stage." 55

\section{e. Access to housing}

Despite the tabloid media's perception that irregular migrants take precedence over British nationals in housing queues, ${ }^{56}$ the former have minimal access to publically-funded housing. Furthermore, the application process for council housing is complex and requires substantial evidentiary proof. Thus, there is very little chance of an irregular immigrant gaining access to social housing through forgery or deception. Instead, they are compelled to find housing on the private rented sector.

The UK's private housing market is relatively unregulated when compared to its European neighbours. Private landlords do not have to register themselves with the state unless they own large multiple-occupancy housing. ${ }^{57}$ They are not responsible for notifying the authorities when there is a new tenant. Furthermore, until recently, although many landlords and letting agents made checks on prospective tenants - for instance, asking to see evidence of identity, the tenant's prior history of rental payments or seeking third party references - these were aimed at protecting the landlord's assets and revenues, rather than statutory immigration measures. 
In the past couple of years, however, the private rental market has been subject to ever more intensive surveillance. Following protracted struggle, the Immigration Act 2014 has recently introduced requirements for landlords to conduct immigration checks on tenants, with financial penalties for those who provide rented accommodation to illegal non-EEA migrants unless they have carried out sufficient checks. If a landlord declines to provide accommodation to a prospective tenant because they cannot produce satisfactory documentation, there would be no legal duty on the landlord to report the person to the Home Office, although s/he is free to do so.

The control regime is therefore similar to the system that is in place for employers. In addition - and much like the way in which employer sanctions are discussed - the introduction of landlords controls are discursively tied to the desire to protect "[exploited] illegal migrants [who] in the worst cases...can end up living in overcrowded and poor housing conditions whilst generating significant profits for unscrupulous landlords." ${ }^{58}$ However, there is an obvious contradiction in approach, insofar as the "the primary objective of the policy is to make it more difficult for illegal migrants to gain access to privately rented accommodation" and "to encourage [them] to choose to leave the country". 59

The resident landlord's association strongly opposed the landlord controls, using similar discourses to those by employer associations during the introduction of employer sanctions. First and foremost, they argued that controls would imply 'unwanted 'red tape' and additional costs for landlords. Second, they argued that the checks would be ineffective, given that they place the onus for enforcement on untrained staff and because illegal immigrants refused by one landlord would 'simply move on either to an ignorant landlord who does not check or an unscrupulous landlord who will take them on anyway' (RLA, 2013: 9). Finally, they also criticised the proposals because of the risk of 'unintended discrimination' by landlords who are scared of penalties (ibid, p. 5).

Given the profits that landlords have made from exploiting irregular immigrants, it is an open question as to whether the resident landlord association's concern for the welfare of immigrants is heartfelt. However, the Immigration Law Practitioners' Association also voiced opposition to the introduction of housing controls. Their major argument was that "people lawfully in the UK, including British citizens, cannot always produce identity documentation' (ILPA, 2013: 2). This is not 
understood as a mere administrative technicality. Instead, they quoted the Home Secretary's introduction to the second reading of the Identity Documents Bill, in which he argued that 'We are a freedom-loving people... discomfort [towards ID cards is] born of a very healthy and British revulsion towards bossy, interfering, prying, wasteful and bullying Government'(ibid). In doing so, the ILPA framed their opposition in terms of the British character.

\section{Conclusion}

As the article above has discussed, relationships between the different members of the "immigration policing family" are complex. ${ }^{60}$ The key issue is one of conflicting aims and objective. Each actor within the "immigration policing family" has his or her own set of priorities, which may supersede the duty of immigration enforcement or even, undermine it. For private enterprises - in this article, employers and landlords - the primary objective is to facilitate business. Irregular immigrants may be seen as favourable tenants or workers, precisely because of the structural vulnerability implied by their irregular immigration status.

Competing objectives also beset the co-option of state actors. For instance, the police are primarily interested in crime control, doctors with healthcare; health and safety inspectors with working conditions; and teachers with education. As the examples described in the article emphasise, the government does not act with a single mind. Instead, it consists of innumerable agents and institutions struggling to reshape the contours of the state according to their own interests. The problem is that the government has a series of objectives, tunnelled into different departments - and at times, these policies come into conflict with each-other. Third parties' resistance to deputisation reflects the continual renegotiation of a hierarchy of aims within the government itself.

Reluctant third-parties actors use a variety of discourses to support their positions. In the UK, resistance is often couched in nationalistic terms. Political actors in the UK associate their opposition by paying homage to "British values" that supposedly carry greater weight than the duty of immigration enforcement. In particular, the British "love of freedom" and our supposed antagonism 
towards unwarranted state interference constitute an oft-visited discourse in the battle against immigration duties.

A second set of discourses centre on the "unintended discrimination" that controls would visit on the legally resident immigrant or ethnic minority population. Such discourses - although not expressly linked to Britishness in recent debates - nonetheless offer a key insight into notions of belonging in the UK. In particular, by highlighting the damage that immigration controls would do to the ethnic minority population, third actors are paying homage to a long-held self-conception of a Britain which protects the rights of "people long established in this country", ${ }^{61}$ wherever they or their family are from originally. The desire to align oneself with this perspective is particularly strong amongst the police, who continue to struggle in their relationships with ethnic minority communities. At the same time, the introduction of biometric residence permits - while identity cards are resisted for British nationals - undermines the straightforward depiction of Britain as a place where the rights of all are equally respected. While British politicians pride themselves on resisting the introduction of identity cards for British nationals on the grounds of civil liberties and a deeply felt cultural allegiance to personal freedom, ${ }^{62} \mathrm{BRPs}$ are rolled out across the foreign population. The fact that these considerations are not extended to foreign nationals undermines another facet of the national myth: the view of Britain as a multicultural haven.

Third parties also consistently use notions of irregular migrants' welfare to justify their opposition to immigration control. The relative success of certain groups (e.g. teachers) versus others (e.g. doctors) in appealing to public sympathy and ultimately, being able to deny immigration enforcement duties on this basis is indicative of a hierarchy of deservedness in the British context. In particular, the irregularly resident child at the school gate apparently carries greater political clout than the sick, but ineligible immigrant turning up at the hospital. A key difference between the two symbolic figures is their intention - the fact that the child is unable to make the decision to immigrate illegally justifies their claim to educational rights. In turn, such a conceptualisation implies that the intention of the person in question carries greater moral weight than the extent of their need. Whether or not this is justifiable is beyond the scope of the present article, but it remains that the relative 
success of the two groups of actors provides a key insight into construction of a public value system in Britain.

Other questions are raised in cases where both the former UK Border Agency and the third party claim that their policy positions are motivated by concern for irregular immigrants. Notably, the use of a "discourse of care" by the UKBA - that is, a claim that immigration enforcement is motivated by a desire to protect the exploited - only happens in the case of private third parties such as employers and landlords because it is easy to understand the commercial advantages that these actors gain from irregular immigration. It is difficult to resist scepticism when employers and landlords claim their resistance to immigration control duties comes from a place a concern for irregular immigrants' welfare - not least because they tend to find ways of taking advantage even when controls are implemented. For instance, subsequent to the introduction of the civil penalty regime, campaigners for the Justice for Cleaners reported a number of incidents relating to employers' use of document checks against unionised migrant cleaners, including threatening workers with dismissal if they took part in industrial action and suspending workers without pay until they submitted documents for re-checking. In these cases, employers found it convenient to 'discover' that the documents that they previously accepted were not genuine (Evans, 2008: 20). In addition, employers appear to be offsetting the increased risk of detection by paying lower wages to irregular migrants (Scott, 2012).

By contrast, it would be difficult to argue convincingly that humanitarian actors such as doctors, teachers, labour inspectorates, police officers and the Immigration Law Practitioners' Association are primarily motivated by the desire to exploit irregular immigrants. In turn, humanitarian actors have so far avoided the sanctions which private third parties are confronting, although a worrying trend in this direction is the prosecution of "humanitarian smugglers" under the offence of assisting unlawful immigration (Aliverti, 2013: 49). It remains to be seen whether punishments will creep across to these members of the "immigration policing family" too.

Despite the smokescreen of concern, immigration authorities' foremost aim is unavoidably clear. The introduction of internal controls is primarily motivated by the desire to deter irregular immigration through making it difficult to live on national territory - although the extent to which this 
policy objective will actually be realised remains uncertain. In particular, "policy implementation in the end comes down to the people who actually implement it" (Lipsky, 1980: 8) - and as above, the consensus of implementing actors is clearly not a given. At the same time, the fear of deportation is so strong that even a small chance of discovery deters many irregular immigrants from making contact with any type of authority.

Even if controls do prevent irregular migrants accessing jobs, housing, and education, it does not necessarily follow that this will either deter future immigrants from coming to the country - or encourage irregular immigrants to leave the country. Many will stay here regardless. Instead, the likely outcome for at least part of this population is widespread destitution, as well as increased recourse to informal and illegitimate social structures as irregular immigrants are pushed "underground" (Engbersen and Broeders, 2009). Given the fundamental, intractable contradictions between immigration enforcement and immigrants' welfare, the utmost scepticism is therefore reserved for the muddy discourses of the UK Border Agency and any future attempt by immigration authorities to feign care for those they deport.

Bibliography

Aliverti, A. (2011) Making home safe? The role of criminal law and punishment in British immigration controls, Oxford University: Oxford

Aliverti, A. (2013) Crimes of Mobility: Criminal Law and the Regulation of Immigration, Routledge: Abingdon

Anderson, B. (2012) "Where's the Harm in That? Immigration Enforcement, Trafficking, and the Protection of Migrants' Rights", American Behavioral Scientist 56(9): 1241-1257.

Broeders, D. (2009) Breaking down anonymity: digital surveillane of irregular migrants in Germany and the Netherlands, Amsterdam University Press: Amsterdam

Broeders, D. and G. Engbersen (2007) "The Fight Against Illegal Migration: Identification Policies and Immigrants' Counterstrategies", American Behavioral Scientist 50(12): 15921609.

Düvell, F. (2008) Report from the UK in J. J. Doomernik, M. (eds.), Modes of migration regulation and control in Europe Amsterdam University Press: Amsterdam

Engbersen, G. and D. Broeders (2009) "The State versus the Alien: Immigration Control and Strategies of Irregular Immigrants", West European Politics 32(5): 867-885.

Evans, Y. (2008) "Papers Please" The Impact of the Civil Penalty Scheme on the Employment Rights of Migrants in the UK, Migrants' Rights Network. London Finch, N. (2011) "The rights of irregular migrant children: legal opinion", unpublished. Gibney, M. (2008) "Asylum and the Expansion of Deportation in the United Kingdom1", Government and Opposition 43(2): 146-167.

Guiraudon, V. and C. Joppke (2001) Controlling a new migration world, Routledge: London 
Hamilton-Smith, N. and S. Patel (2006) Determining identity and nationality in local policing, Home Office Research Report 42.

Hendriks, A. and B. Toebes (1998) "Towards a universal definition of the right to health?", Medicine and law 17(3): 319.

ILPA (2013) ILPA Information Sheet, 'Tackling illegal immigration in privately rented accommodation': Home Office Consultation, Immigration Law Practioners' Association. London

Jones, T., M. Ram, et al. (2006) "Ethnic minority business and the employment of illegal immigrants", Entrepreneurship \& regional development 18(2): 133-150.

Jordan, B., Düvell, F. (2002) Irregular migration : the dilemmas of transnational mobility, Edward Elgar: Cheltenham

Karlson, S. H. and E. Katz (2003) "A positive theory of immigration amnesties", Economics Letters 78(2): 231-239.

Kmietowicz, Z. (2004) "GPs to check on patients' residency status to stop "health tourism"'", BMJ: British Medical Journal 328(7450): 1217.

Kupiszewski, M. M., H. (2008) Addressing the irregular employment of immigration in the European Union: Between sanctions and rights, IOM.

Lahav, G. (1998) "Immigration and the state: The devolution and privatisation of immigration control in the EU", Journal of Ethnic and Migration Studies 24(4): 675 - 694.

Lipsky, M. (1980) Street-level bureaucracy: Dilemmas of the individual in public services, Russell Sage Foundation: New York

Macpherson, W. (1999) The Stephen Lawrence Inquiry, Presented to Parliament by the Secretary of State for the Home Department by Command of Her Majesty.

Pollard, A. J. and J. Savulescu (2004) "Ethics in practice: Eligibility of overseas visitors and people of uncertain residential status for NHS treatment", BMJ: British Medical Journal 329(7461): 346.

RLA (2013) Tackling illegal immigration in privately rented accommodation. The RLA's response to the Home Office's consultation on immigration checks for tenants, Resident Landlords' Associatio. Manchester

Ryan, B. (2007) Revisiting Employer Sanctions in the United States and Europe, Institute for the Study of International Migration, Walsh School of Foreign Service, Georgetown University.

Scott, P. (2004) Undocumented Migrants In Germany And Britain: The Human Rights And Wrongs Regarding Access to Health Care. Electronic Journal of Sociology

Scott, S., Craig, G., Geddes, A. (2012) Experiences of forced labour in the UK food industry, Joseph Rowntree Foundation.

Sigona, N. and V. Hughes (2012) No way in, no way out, Irregular migrant children and families in the UK, COMPAS. Oxford

Singer, R. (2004) "Asylum seekers: an ethical response to their plight", The Lancet 363(9424): 1904.

Toebes, B. (1999) "Towards an improved understanding of the international human right to health", Human Rights Quarterly 21(3): 661-679.

Trade Union Congress (2010) Immigration Document Checks and Workplace Raids, a negotiators' guide, TUC.

Vogel, D. (2000) "Migration Control in Germany and the United States", International Migration Review 34(2): 390-422.

Warren, A. and E. Mavroudi (2011) "Managing Surveillance? The Impact of Biometric Residence Permits on UK Migrants", Journal of Ethnic and Migration Studies 37(9): 14951511. 
1 "Tackling illegal immigration in privately rented accommodation, consultation document", Home Office, 3 July 2013, accessible at: http://www.ukba.homeoffice.gov.uk/sitecontent/documents/policyandlaw/consultations/33-

landlords/consultation.pdf?view=Binary p. 10

2 'David Cameron's immigration speech' [online]

https://www.gov.uk/government/speeches/david-camerons-immigration-speech.

${ }^{3}$ To use a term found in Lahav (1998)

${ }^{4}$ The concept of a "policing family" is borrowed from Crawford, A. \& Lister, S. (2004) "The extended policing family: Visible patrols in residential areas" (published by the Joseph Rowntree Foundation). In both the original and the present article, it refers to the "reasonably well established mixed economy" (Crawford and Lister 2004: viii) of institutions performing policing tasks.

${ }^{5}$ Unauthorised foreign employment includes the employment of foreigners without the right of residence; foreigners with the right of residence and without the right to work; and finally, foreigners with the right of residence and right to work, but who are employed in a manner that contravenes the conditions of their immigration status (see (Kupiszewski, 2008)) The current article primarily focuses on foreigners without the right of residence.

6 "Businessmen bid to block bill. Immigration Scheme angers Employers. Anger at Immigration Scheme", Herald Scotland, 25 October 1995, accessible at: http://www.heraldscotland.com/sport/spl/aberdeen/businessmen-bid-to-block-billimmigrant-scheme-angers-employers-anger-at-immigrant-scheme-1.654879

${ }^{7}$ Carelessly here implies employers who have hired foreign workers without undertaking a proper check of their documents and entitlement to work. This offence is used where intention of criminal wrongdoing cannot be proved (Aliverti, 2011)

${ }^{8}$ Freedom of Information Request 3697, Department of Work and Pensions.

${ }^{9}$ The Immigration and Nationality Directorate is the organisation preceding the UK Border Agency, which has now been subsumed into the "Immigration Law Enforcement" unit within the Home Office.

${ }^{10}$ See "Immigration Control: Fifth Report of Session 2005-06, Volume 1" By Great Britain: Parliament: House of

Commons: Home Affairs Committee p.112

${ }^{11}$ Freedom of Information Request 3697, Department of Work and Pensions

12 Under Section 122B of the Social Security Administration Act (SSAA) 1992

${ }^{13}$ Freedom of Information request, 24287, UK Border Agency

${ }^{14}$ Freedom of Information request, 24287, UK Border Agency

${ }^{15}$ Parliamentary debates, "Illegal Immigrants: Employment", 11 February 2009: Column 2045w, accessible at: www.publications.parliament.uk/pa/cm200809/cmhansrd/cm090211/text/90211w0016.htm

16“"Thousands of jobs under threat UK Border Agency", Public and Commercial Services Union, 9 Jule 2010, accessible at: http://www.pcs.org.uk/en/news_and_events/news_centre/index.cfm/id/11D4FD0C-99D9-42DF-94514665E681BE3E

${ }_{17}$ Freedom of Information request 13-1133, Employment Agency Standards Inspectorate

18“"Topic Inspection Pack: Migrant Working", Health and Safety Executive, revised March 2010, p.51 accessible at: http://www.hse.gov.uk/foi/internalops/fod/inspect/migrantworker.pdf

${ }^{19}$ Joint Workplace Protocol for sharing information between the HSE and other Government departments and agencies, accessible at: http://www.hse.gov.uk/foi/internalops/ocs/001-099/84_6/index.htm

${ }^{20}$ Freedom of Information request, PF/AW

${ }^{21}$ Freedom of Information request, 2013080368

22 "The Grabiner Report", HM Treasury, accessible at: http//archive.treasury.gov.uk/pdf/2000/grabiner.pdf

${ }^{23}$ This included a tiny pilot project of joint shadow economy teams, which concluded 2006, see

www.eurofound.europa.eu/areas/labourmarket/tackling/cases/uk004.htm

${ }^{24} \mathrm{http} / \mathrm{hmrc}$.gov.uk/manuals/idgmanual/IDG55120.html, last accessed 25.10.2012, no longer available

${ }^{25}$ Deportation, HC Deb 23 March 1977 vol 928 cc540-1W, accessible at

http://hansard.millbanksystems.com/written_answers/1977/mar/23/deportation\#S5CV0928P0_19770323_CWA_31

${ }^{26}$ Freedom of Information requests: London (FOI 2012080002362); Devon (FOI 002731/12); Suffolk (FOI 597/11/12.)

27 Even far-right politician Nigel Farage has condemned the checks, arguing that they are "un-British", see: http://www.telegraph.co.uk/news/uknews/immigration/10219174/Nigel-Farage-attacks-Home-Office-immigrant-spotchecks-as-un-British.html

${ }^{28}$ The UKBA set up a hotline for police officers. There is also an option for searching UKBA records when carrying out fingerprint scans through LiveScan. Finally, since the roll out of the Police National Database in 2010, police can scan identity documents as well. See (Hamilton-Smith and Patel, 2006)

29“UKBA "ignored" police data on missing asylum seekers", BBC, 26 June 2013, accessible here: http://www.bbc.co.uk/news/uk-23056052

${ }^{30}$ Former legal aid solicitor, interviewed in the course of doctoral research, 03.06.2012

${ }^{31}$ See the International Convention on Economic, Social and Cultural Rights 1966 (entry into force January $3^{\text {rd }}$, 1976), which does not make distinctions between legal and "illegal" foreigners; and the International Convention on the Protection of the Rights of All Migrant Workers and Members of Their Families, December $18^{\text {th }} 1990$, particularly Art. 28 (as discussed in (Scott, 2004)accessible at: http://www.sociology.org/content/2004/tier2/scott.html

${ }^{32} \mathrm{R}$ v Barnet LBC Ex p Shah (Nilish) 1983 2AC $309 \mathrm{HL}$

${ }^{33}$ Notable exemptions to this rule are "immediately necessary" treatments, which must be provided in advance of payment, and public health services, which include treatment for tuberculosis and sexually transmitted diseases, excluding HIV (Pollard and Savulescu, 2004). 
34“Controlling Immigration - Regulating Migrant Access to Health Services in the UK, consultation document”, Home Office, Consultation document, 3 July 2013, accessible at:

http://www.ukba.homeoffice.gov.uk/sitecontent/documents/policyandlaw/consultations/34-healthcare/consultationhealth.pdf?view=Binary

${ }^{35}$ See: "GPs forced to register illegal immigrants after threat of legal action", Pulse, 22/12/2011, accessible at: http://www.pulsetoday.co.uk/gps-forced-to-register-illegal-immigrants-after-threat-of-legal-action/13234713.article

${ }^{36}$ Under section 83 of the NHS Act 2006

${ }^{37}$ Supra note 36, p.22

${ }^{38}$ Dr Laurence Buckman, chair of the British Medical Association's GP Committee, quoted here: http://bma.org.uk/newsviews-analysis/news/2013/july/overseas-nhs-visitor-charges-require-more-thought-warn-doctors-leaders

39 'Don't turn GP surgery into a border agency”, BBC , 03/07/2013, accessible at: http://www.bbc.co.uk/news/health23160057

40 "Foreigner face more charges to access the NHS", BBC, 03/07/2013, accessible at: http://www.bbc.co.uk/news/health23156403

41"Implementing the Overseas Visitors Hospital Charging Regulations. Guidance for NHS Trusts in England”, Department of Health, April 2004, p.40

${ }^{42} \mathrm{~W}$ v Edgell [1990] 1 ALL ER 835

${ }^{43}$ FOI 2013.08.001. It has also received information 30 times in same time period.

${ }^{44}$ Immigration lawyer, interviewed in the course of doctoral research 24.06.2012

45 "Access to Health Care is a right worth defending", Migrant Rights Network, January 2011, accessible at: www.migrantsrights.org.uk/files/Access-to-Health-Care.pdf

46"Ministers planning immigration crackdown on "education tourists"”, The Guardian, 27 March 2013, accessible at: http://www.theguardian.com/politics/2013/mar/27/ministers-immigration-crackdown-education-tourists

${ }^{47}$ Reported in "Ministers planning immigration crackdown on 'education tourists"', Shiv Malik and Peter Walker, The Guardian, 27 March 2013, accessible at: http://www.theguardian.com/politics/2013/mar/27/ministers-immigrationcrackdown-education-tourists

${ }^{48}$ Supra note 48

49 "Immigration - press release", Christine Blower, General Secretary of the National Union of Teachers, accessible at: http://www.teachers.org.uk/node/17936

${ }^{50}$ Note that irregular migrant children raised in the UK do not qualify as a Tier 4 (General) Student Migrant, see (Finch, 2011)

51 "Bogus college check catches 124", BBC News, 8 January 2008, accessible at: http//news.bbc.co.uk/1/hi/education/7177033.stm

52“London Metropolitan University's licence revoked”, Department for Business, Skills and Innovation, 30/08/2012, accessible at: https://www.gov.uk/government/news/london-metropolitan-universitys-licence-revoked

53 "British visa ruling leaves thousands in limbo", International Herald Tribune, 03 September 2012

54"Final Report: Cost and benefit analysis project on immigration regulation", Higher Education Better Regulation Group, 11 July 2013 , accessible at:

http://www.hebetterregulation.ac.uk/NewsEventsPublications/News/Documents/HEBRG\%20Tier\%204\%20Final\%20Report $\% 20(11 \% 20 J U L Y \% 202013) . p d f$

55 "Overseas students say immigration cap makes them feel less welcome in UK", Universities and Colleges Union, 24/06/2013, accessible at http://www.ucu.org.uk/6683

${ }^{56}$ See "Illegal immigrant mum gets four-bedroom house", The Sun, 25/05/2010, for a classic example (accessible at: http://www.thesun.co.uk/sol/homepage/news/2867802/Illegal-immigrant-mum-gets-four-bedroom-house.html )

${ }^{57}$ Under the Housing Act 2004, S. 61 and secondary legislation made under that Act

58 Ibid, p. 3

${ }^{59}$ Ibid, p. 7

60 The problem is partially one of miscommunication. The UK Border Agency was, at its

closure, beginning to build up the technical infrastructure and administrative pathways to support the

flow of information between agencies, although the extent to which these possibilities were used is another story entirely. In particular, the repeated failings of the UKBA did little satisfy other key agencies that cooperation was worthwhile.

${ }^{61}$ See, for instance, "Immigration and Race Relations", HC Deb 06 December 1973 vol 865 cc1546-82, accessible at: http://hansard.millbanksystems.com/commons/1973/dec/06/immigration-and-race-relations-1

62 'Laying ID cards to rest demonstrates the government's commitment to scale back the power of the state and restore civil liberties...This is just the first step in the process of restoring and maintaining our freedoms.' Home Office Minister Damian 
Green, see https://www.gov.uk/government/news/national-identity-register-destroyed-as-government-consigns-id-cardscheme-to-history 